\title{
Energetic optimization of the use of battery shunting locomotive in industrial plant with regenerative brake
}

\author{
Tsvetomir Gotsov $\ddagger$, Venelin Todorov*广 ${ }^{* \dagger}$ Tsvetelin Kolev ${ }^{\S}$ \\ *Institute of Mathematics and Informatics \\ Bulgarian Academy of Sciences \\ 8 Acad. G. Bonchev Str., 1113 Sofia, Bulgaria \\ $\dagger$ Institute of Information and Communication Technologies \\ Bulgarian Academy of Sciences \\ 25A Acad. G. Bonchev Str., 1113 Sofia, Bulgaria \\ ‡Electronics Department, University of Ruse, Bulgaria \\ $\S_{R} \& D$ Department Express Service OOD, Ruse, Bulgaria \\ Email: vtodorov@math.bas.bg, venelin@parallel.bas.bg, tsvetomir.gotsov@gmail.com, info@1z1866.com
}

\begin{abstract}
Shunting locomotives perform specific functions characterized by short mileages, variable load weights and a high idling rate. Battery technology based on traction is a very suitable solution for shunting locomotives due to the possibility of accumulating kinetic energy in the power supply. The optimization of the energy efficiency of regenerative braking and the possibilities for efficient shunting in industrial plant were studied.
\end{abstract}

\section{INTRODUCTION}

Maneuvering activity is a major operation performed on the territory of freight yards, in passengers terminal stations, depots, in industrial plants connected to rail network, in harbours and multimodal terminals. Industrial sites connected to the rail network own shunter locomotives for freight wagons shunting on their premises. In order to be able to operate independently from the overhead voltage, or on non-electrified rail, most shunter locomotives are diesel electric or diesel hydraulic locomotives [1]. Diesel engines typically operate in an inefficient mode, which in a competitive business environment makes them economically unprofitable. To a great extent, this is aided by the rising fuel prices over the past decade and the high maintenance costs of conventional engines. In the case of battery-powered locomotives, these costs are reduced to the maintenance costs of the used battery. Machines on batteries have the possibility of regenerative braking, which enables the kinetic energy to be transformed into electric and re-accumulated in the battery [12]. Interesting is the energy efficiency of this type of braking and its benefits for shunting locomotives.

Venelin Todorov is supported by KP-06-M32/2-17.12.2019 'Advanced Stochastic and Deterministic Approaches for Large-Scale Problems of Computational Mathematics" and by the National Scientific Program "Information and Communication Technologies for a Single Digital Market in Science, Education and Security" (ICTinSES), contract No. D01-205/23.11.2018, financed by the Ministry of Education and Science.

\section{OPERATION OF SHUNTING LOCOMOTIVES}

There is clearly a very great diversity of shunting duties depending from local railways configuration and practices. But it is possible to identify some common characteristics:

- Shunting is operated at low speed, typically below $15 \mathrm{~km} / \mathrm{h}$.

- The distance traveled with the shunted vehicle or train is relatively short less than $5 \mathrm{~km}$

- The loads to shunt vary in a wide range from the mass of a shunting locomotive to several thousand tons.

When maneuvering with train braking or unloading special types of wagons, large amounts of compressed air are required, which requires the use of powerful air compressors in this type of locomotive. A special feature of the shunting movements is that the locomotive does not leave its place of work and in a large percentage of cases it has access to standard industrial voltage. This feature of shunting locomotives allows the use of batteries tailored to a single shift for a particular application and a minimum volume and power of the locomotive.

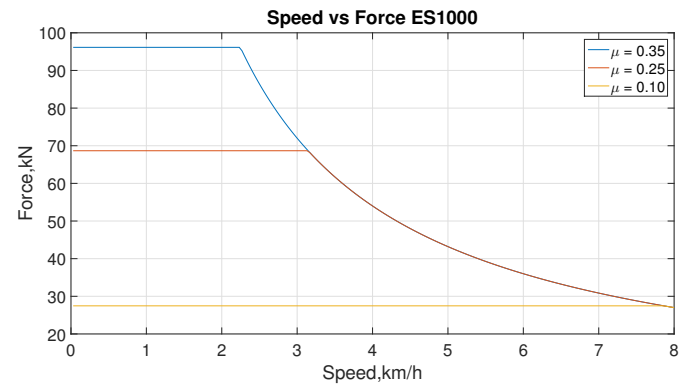

Fig. 1. Traction characteristics ES1000 Shunting locomotive 


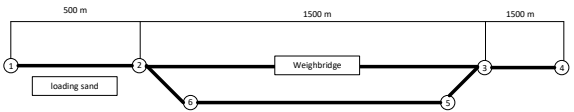

Fig. 2. Railway from industrial plant

The track development of an industrial plant for loading chamotte shows Fig 2. In section 1-2 carriage of wagons is carried out by laying on each wagon.

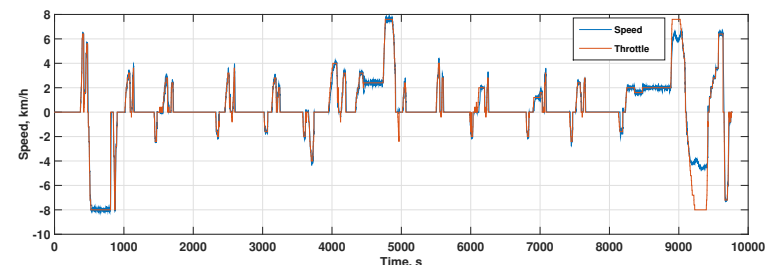

Fig. 3. Typical speed mode when loading 12 freight wagons with chamotte in industrial plant.

The mode at which this task is performed can be seen in Fig. 3 in the range $1000-8000$ s. After filling all the wagons, the composition passes through the Weighbridge in section 23 and interval 8000-9000s. Fig. II. Continue to section 3-4 for a change of the rail. In section 5-6 there is a stay of full wagons, ready to travel on national infrastructure. After the interval 8000 s. in Fig. 3 is the hardest job of the locomotive in which it draws $960 t$. The diagram in Fig. 3 shows: in orange the set speed reference and in blue the current engine speed for the entire period of the study. Negative speed marks a backward movement.

\section{THE SYSTEM UNDER STUDY}

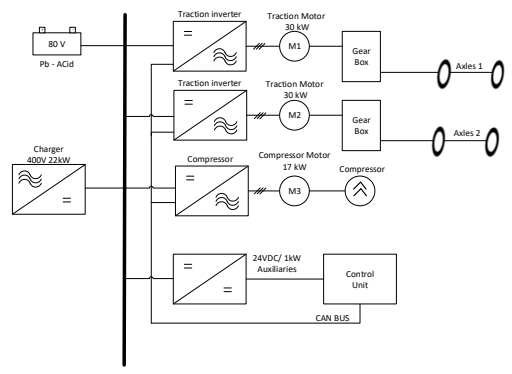

Fig. 4. Electrical diagram from battery shunting locomotive.

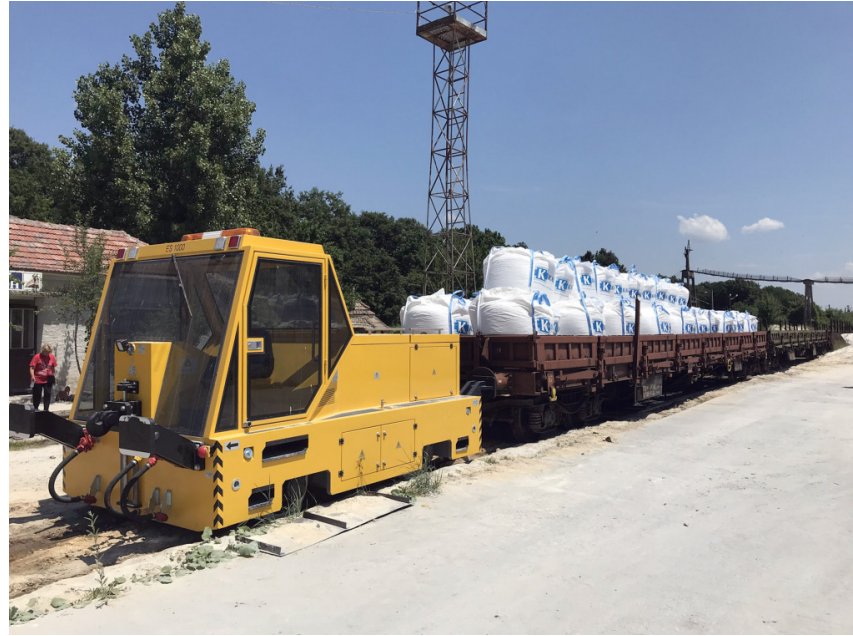

Fig. 5. ES1000 in working conditions.[2]

Shunting locomotives differ from highway locomotives with the lower power and maximum speed they possess. Battery Shunting locomotives in turn differ with extremely low power due to technological disadvantages of modern sources for energy storage, namely, low density and massive mass. Schematic diagram of an ES1000 shunting locomotive represented in Fig. 4. The locomotive has two axles and has a total weight of $28 t$. Each wheel is powered by Induction Motor with a power of $30 \mathrm{~kW}$. There is also an Induction Motors of $17 \mathrm{~kW}$ to drive the air compressor. Control of the electric motors is carried out by a four quadrant vector control. As a power source, Lead-Acid Battery with a capacity of $1356 \mathrm{Ah}$ and a voltage of $80 \mathrm{VDC}$ is used. The total stored power of the locomotive equals $390 \mathrm{MJ}$, sufficient to provide energy for one work shift. Battery is the oldest electric energy stored technology. A battery consists of multiple electrochemical cells, connected in parallel and series to form a unit. Cells consist of two electrodes immersed in an electrolyte solution. Batteries work based on the following principle: due to reversible chemical reactions that occur at the electrodes, a potential difference appears between them. Consequently, energy can reversibly change from electrical form to the chemical form [4], [14], [15]. The Lead-Acid battery is unpretentious to the charge current and for short periods can resist larger circuit currents. Charge of the battery from the power grid takes 5 hours, from a fully discharged battery. The maximum discharge current of the traction inverter is $650 \mathrm{~A}$ each. The maximum allowed discharge current of the entire system is:

$$
\begin{gathered}
I_{\text {dischargemax }}=I_{\text {traction } 1}+I_{\text {traction } 2}+I_{\text {comp. }}+I_{\text {aux. }}= \\
=650+650+150+50 \approx 1500 \mathrm{~A}
\end{gathered}
$$

Current with this value is peak and it lasts less than a minute. The control is carried out by the Control Unit and the distributed system from the traction controllers. All electronics 
device connected in CAN-bus network. Data capture is done via the Serial port of the traction inverter. Data is recorded by an additional installed logger on the shunting locomotive with a sampling time of $0.5 \mathrm{~s}$. Data recording begins immediately after the locomotive exits the Depot for the interval 0-1000s /Fig. 3/ and ends at Depot's place for charge. Locomotive in the experimental conditions of an industrial plant shows in Fig. 5.

\section{Results}

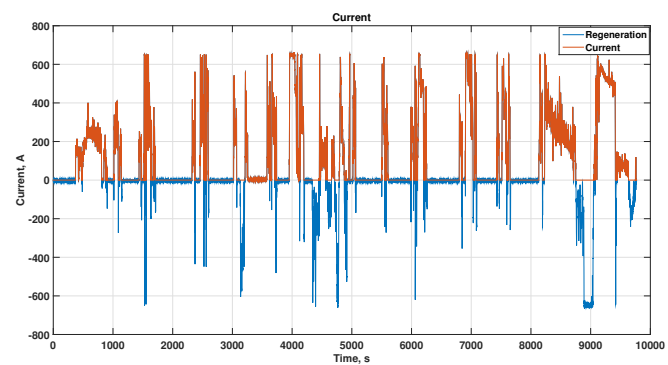

Fig. 6. Traction current $\log$ from traction inverter 1

The experiment was carried out in an industrial plant for loading chamotte. Fig. 6 shows a current log consumed by $M 1$ for one working cycle $(t \approx 10000 s$. ). The orange graph is the consumed current, and the blue one is the current returned to the battery, marked with a reverse sign. In the conducted trials, the train stop is performed only by a traction engine. The train brake is switched on but not in use. Its goal is to increase the security of shunting.

The stored kinetic energy $E_{k}$ during movement with a $960 t$ train and a speed of $8 \mathrm{~km} / \mathrm{h}$ is:

$$
E_{k}=\frac{m v^{2}}{2}=\frac{960 t(8 \mathrm{~km} / \mathrm{h})^{2}}{2}=4,7 \mathrm{MJ}
$$

In case of braking, this energy must be scattered into the atmosphere in the form of heat or re-accumulated in the form of electrical energy. Modern propulsion technologies enable much of this energy to be absorbed and reused. These capabilities of electric locomotives and especially battery locomotives create the opportunity to increase energy efficiency in rail transport. The change in battery voltage is illustrated in Fig. 7. The nominal voltage is $80 \mathrm{~V}$ but due to the large discharge currents, it drops to $55 \mathrm{~V}$ at discharge and increases to $95 \mathrm{~V}$ in the regeneration brake and charge from the Traction inverter.

The energy consumed without regenerative braking for the shunting cycle:

$$
E_{\text {brake }}=\int_{0}^{T} u(t) i(t) d t=85.5 \mathrm{MJ}
$$

The energy consumed with regenerative braking for the shunting cycle:

$$
E_{\text {regbrake }}=\int_{0}^{T} u(t) i(t) d t=60.7 M J
$$

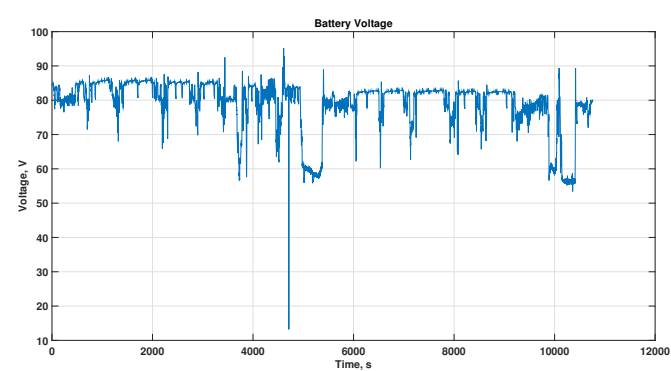

Fig. 7. Voltage drop for Lead -Acid battery

Energy efficiency from the use of regenerative braking:

$$
E E=\left(\frac{E_{\text {brake }}}{E_{\text {regbrake }}}-1\right) * 100=41 \%
$$

The research is done from recorded data on one of the traction inverters. The total power consumption of the two drives and the air compressor is $219 M J(61 k W h)$ measured as the electricity required to charge the battery from the power grid. For the same amount of work done with a diesel locomotive, the energy consumed equals 80 liters of diesel fuel. The data for about $41 \%$ efficiency is also confirmed by other publications related to the study of regenerative braking energy efficiency [3-8,17-25]. The one-year electricity savings during similar work operations from the use of a regenerative brake is approximately:

$$
E_{\text {reg }}=E_{\text {brake }}-E_{\text {regbrake }}=6000 \mathrm{MJ}=1.6 \mathrm{MW} \mathrm{W} / \mathrm{h}
$$

The economic benefit of using a battery shunting locomotive instead of manoeuvrable diesel engine is the electricity consumption for a year /instead of diesel fuel/:

$$
E_{\text {total }}=(240 \text { workingdaysright })(61 \mathrm{~kW} / \mathrm{h})=14640 \mathrm{~kW} / \mathrm{h}
$$

Diesel fuel consumption per year for the same type of work is:

$$
\text { Dieselfuel }=(240 \text { workingdays })(80 L)=19200 L
$$

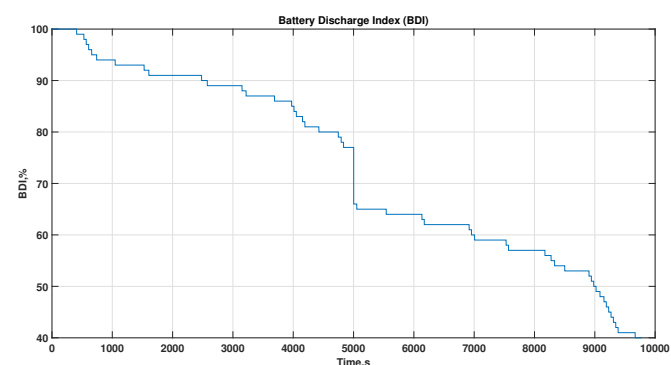

Fig. 8. Battery discharge index for Lead-Acid 
Consumption of energy from the battery illustrates Fig. 8 . It could be seen that for the given work cycle, loading and shunting of 12 chamotte wagons, the battery has rendered all of its energy up to 40 .

For larger volumes of work, the capacity of the battery can be increased in accordance with a particular application. The locomotive works during different periods of the year under different climatic conditions in a moderate climate with success and without failures or change in performance. At ambient temperatures of $-20 \mathrm{C}$, changes in battery capacity do not have a significant effect on the performance. Despite the small number of Lead-Acid Battery cycles and shorter lifetime than alternative options, their life may exceed 10 years in normal exploitation. At this price point these type of batteries used in vehicles remain the cheapest solution [9], [20].

\section{CONCLUSION}

This article explores the energy efficiency optimization of regenerative braking in shunting locomotives instead of the conventional braking with the automatic train brake. LeadAcid technology has been studied to power and store energy. Regenerative braking optimizes shunting costs and reduces wear on train braking systems. Electric battery shunting locomotives provide a real opportunity to reduce emissions in cities and industrial plants. The reduction of harmful emissions in railway transport has emerged as a strategic task for the Union of Railways with a database of technologies enabling optimization of the energy efficiency. The ability to charge the battery from renewable energy sources allows us to achieve zero emission. In the future work some other techniques for energy optimization will be discussed.

\section{REFERENCES}

[1] http://www.railway-research.org/IMG/pdf/r.2.2.3.1.pdf (accessed on May 2019)

[2] http://lz1866.com/battery-locomotives\#es (accessed on 2 May 2019)

[3] M. Ogasa, Energy saving and environmental measures in railway technologies: Example with hybrid electric railway vehicles, IEE Trans. Electr. Electron. Eng., vol. 3, no. 1, pp. 15-20, 2008 DOI: $10.1002 /$ tee. 20227

[4] M. Khodaparastan, A. A. Mohamed, and W. Brandauer, Recuperation of regenerative braking energy in electric rail transit systems, IEEE Trans. Intell. Transp. Syst., vol. 20, no. 8, pp. 2831-2847, 2019. DOI:10.1109/TITS. 2018.2886809

[5] R. Takagi, Energy saving techniques for the power feeding network of electric railways, IEEJ Trans. Electr. Electron. Eng., vol. 5, no. 3, pp. 312-316, 2010. DOI:10.1002/tee.20535

[6] M. Shimada, R. Oishi, D. Araki, and Y. Nakamura, Energy storage system for effective use of regenerative energy in electrified railways, Hitachi Rev., vol. 59, no. 1, pp. 33-38, 2010. ISSN 0018277X

[7] M. Saleh, O. Dutta, Y. Esa, and A. Mohamed, Quantitative analysis of regenerative energy in electric rail traction systems, 2017 IEEE Ind. Appl. Soc. Annu. Meet. IAS 2017, vol. 2017-Janua, pp. 1-7, 2017. R. Nicole, Title of paper with only first word capitalized, J. Name Stand. Abbrev., in press. DOI:10.1109/IAS.2017.8101774
[8] Available online: https://www.alstom.com/sites/alstom.com/files/2018/ 10/30/re-use_laymans_report_en.pdf (accessed on 9 May 2019).

[9] UIC, Energy Efficiency Technologies for Railways. Available online: http://www.railway-energy.org (accessed on 9 May 2019).

[10] M. Steiner and J. Scholten, Energy storage on board of railway vehicles, 2005 Eur. Conf. Power Electron. Appl., vol. 2005, pp.1-10, 2005. DOI: $10.1002 /$ tee. 20535

[11] R. Takagi, Application of energy storage systems for DC electric railways, WIT Trans. Ecol. Environ., vol. 121, pp. 527-535, 2009. DOI: $10.2495 / E S U 090481$

[12] X. Luo, J. Wang, M. Dooner, and J. Clarke, Overview of current development in electrical energy storage technologies and the application potential in power system operation, Appl. Energy, vol. 137, pp. 511536, 2015. DOI:10.1016/j.apenergy.2014.09.081

[13] A. Gonzalez-Gil, R. Palacin, and P. Batty, Sustainable urban rail systems: Strategies and technologies for optimal management of regenerative braking energy, Energy Convers. Manag., vol. 75, pp. 374-388, 2013. DOI:10.1016/j.enconman.2013.06.039

[14] W. Gunselmann, Technologies for increased energy efficiency in railway systems, 2005 Eur. Conf. Power Electron. Appl., vol. 2005, pp. 1-10, 2005. DOI:10.1109/epe.2005.219712

[15] J. Hu, Y. Zhao, and X. Liu, The design of regeneration braking system in light rail vehicle using energy-storage Ultra-capacitor, 2008 IEEE Veh. Power Propuls. Conf. VPPC 2008, pp. 1-5, 2008.DOI:10.1109/VPPC.2008.4677708

[16] M. Miyatake and K. Matsuda, Energy saving speed and charge/discharge control of a railway vehicle with on-board energy storage by means of an optimization model, IEEJ Trans. Electr. Electron. Eng., vol. 4, no. 6, pp. 771-778, 2009. DOI:10.1002/tee.20479

[17] European Commission, Electrification of the Transport System: Studies and Reports, pp. 1-49, 2017. ISBN:9789279718564

[18] A. Fernandez-Rodriguez et al., Charging Electric Vehicles Using Regenerated Energy from Urban Railways, 2017 IEEE Veh. Power Propuls. Conf. VPPC 2017 - Proc., vol. 2018-January, pp. 1-6, 2018. DOI:10.1109/VPPC.2017.8330998

[19] K. Ogura et al., Test results of a high capacity wayside energy storage system using Ni-MH batteries for DC electric railway at New York City Transit, 2011 IEEE Green Technol. Conf. Green 2011, pp. 6-11, 2011. DOI: 10.1109/GREEN.2011.5754859

[20] M. Ceraolo and G. Lutzemberger, Stationary and on-board storage systems to enhance energy and cost efficiency of tramways, J. Power Sources, vol. 264, pp. 128-139, 2014. DOI:10.1016/j.jpowsour.2014.04.070

[21] D. Iannuzzi and P. Tricoli, Speed-based state-of-charge tracking control for metro trains with onboard supercapacitors, IEEE Trans. Power Electron., vol. 27, no. 4, pp. 2129-2140, 2012. DOI:10.1109/TPEL.2011.2167633

[22] D. Iannuzzi and P. Tricoli, Supercapacitor state of charge control based on changeover finite state controller for metro-train applications, 3rd Int Conf. Clean Electr. Power Renew. Energy Resour. Impact, ICCEP 2011, pp. 550-556, 2011.

[23] L. Mir, I. Etxeberria-Otadui, I. P. De Arenaza, I. Sarasola, and T. Nieva, A supercapacitor based light rail vehicle: System design and operations modes, 2009 IEEE Energy Convers. Congr. Expo. ECCE 2009, vol. 146, pp. 1632-1639, 2009. DOI:10.1109/ECCE.2009.5316073

[24] M. Steiner and J. Scholten, Energy storage on board of railway vehicles, 2005 Eur. Conf. Power Electron. Appl., vol. 2005, pp. 1-10, 2005 DOI: $10.1109 /$ epe. 2005.219410

[25] D. Grimaud and J. Levraut, Optimal driving strategy for traction energy saving on DC suburban railways, Minerva Anestesiol., vol. 67, no. 4, pp. 263-270, 2001.DOI:10.1049/iet-epa 